\title{
MODEL LITERASI MEDIA SOSIAL BAGI MAHASISWA
}

\author{
Muhammad Sulthan dan S. Bekti Istiyanto
}

Jurusan Ilmu Komunikasi Fisip Universitas Jendral Soedirman Jl. Kampus No.12, Brubahan, Grendeng, Purwokerto Utara, Kabupaten Banyumas, Jawa Tengah. Email: czhoelthaan@gmail.com; bektiis@yahoo.com

\begin{abstract}
The development of internet communication technology today is unstoppable, especially for students. Many negative impacts have arisen in the use of social media due to wrong use. This study aims to find a social media literacy model for unsoed Purwokerto students. The researcher used a qualitative approach with in-depth interviews, focus group discussions and literature studies as data collection techniques. The subjects of this study were Unsoed Social Sciences Department students who actively use social media every day. The results of the study found a social media literacy model for Unsoed students based on the media literacy model proposed by Potter. Students use social media according to the needs and peculiarities of existing social media, both from exchanging information and maintaining friendships to the reasons for the process of learning, economics, entertainment, and self-actualization; students know of any negative impacts and irregularities that occur due to inappropriate use of social media. However, they still use social media. Such because it is already a demand in everyday life.
\end{abstract}

Keywords: social media, negative impacts, students, media literacy.

\begin{abstract}
Abstrak
Perkembangan teknologi komunikasi internet dewasa ini tidak terbendung menerpa kita, khususnya mahasiswa. Banyak muncul dampak negatif dalam penggunaan media sosial akibat penggunaan yang salah. Penelitian ini bertujuan untuk menemukan model literasi media sosial bagi bagi mahasiswa Unsoed Purwokerto. Peneliti menggunakan pendekatan kualitatif dengan wawancara mendalam, focus group discussion dan studi pustaka sebagai teknik pengumpulan data. Subyek penelitian ini mahasiswa Jurusan Ilmu Komunikasi Fisip Unsoed yang aktif menggunakan media sosial setiap harinya. Hasil penelitian menemukan model literasi media social bagi mahasiswa Unsoed berdasarkan model media literasi yang dikemukakan oleh Potter. Mahasiswa menggunakan media sosial sesuai kebutuhan dan kekhasan media sosial yang ada, baik dari bertukar informasi dan menjaga pertemanan hingga alasan proses pembelajaran, ekonomi, hiburan, dan aktualisasi diri; mahasiswa mengetahui adanya dampak negatif dan penyimpangan yang terjadi akibat penggunaan media sosial yang tidak sesuai. Namun demikan mereka tetap menggunakan Media sosial. Tersebut Karena sudah merupakan tuntutan dalam kehidupan sehari-hari.
\end{abstract}

Kata Kunci: media sosial, dampak negatif, mahasiswa, literasi media.

\section{Pendahuluan}

Jumlah pengguna Internet di Indonesia telah mencapai 132.7 juta orang dari 256.2 juta orang populasi Indonesia. Ini berarti, pengguna Internet di Indonesia telah mencapai $51.8 \%$ dari jumlah penduduk Indonesia seluruhnya. Komposisinya bisa dikatakan berimbang di antara laki-laki $(52.5 \%)$ dan perempuan (47.5\%). Namun demikian, dari segi geografis, pengguna Internet terbesar berada di pulau Jawa sebanyak 65\% (86.3 juta orang), sisanya tersebar di Sumatera (15.7\%), Sulawesi (6.3\%) dan Kalimantan (5.8\%). Dua wilayah 
lainnya yaitu Bali dan Nusa persentasenya di bawah 5\%. Ini memperlihatkan adanya kesenjangan dalam penggunaan Internet (APJII, 2016).

Kenyataan menunjukkan, banyaknya jumlah pengguna internet di Indonesia, serta tingginya frekuensi mengakses konten informasi dan media sosial, tidak serta-merta menjamin 'kedewasaan' netizen Indonesia dalam menggunakan Internet. Selain kesenjangan yang terjadi, berbagai kasus penyalahgunaan Internet juga marak, mulai dari internet fraud, adiksi atau kecanduan, pelanggaran privasi, bias realitas, hingga yang paling mutakhir adalah meluasnya hoax. Jika ditelisik, sejumlah kasus tersebut bermuara pada satu hal, yaitu rendahnya literasi digital masyarakat Indonesia (Kurnia,dkk., 2016).

Menurut lembaga riset pasar e-Marketer, diperkirakan populasi netter atau pengguna internet tahun 2017 di Indonesia mencapai 112 juta jiwa (https://kominfo.go.id/ content/detail/4286/pengguna-internetindonesia-nomor-enam-dunia/0/sorotan media). Begitu besarnya pengguna internet di dunia terutama di Indonesia, sehingga semakin banyak pula bermunculan situssitus baru yang dapat di akses oleh para pengguna internet. Situs-situs jejaring sosial tersebar dengan berbagai kegunaan, seperti: Facebook, Twitter, Instagram, Path, Snapchat, dan Ask.fm. Selain manfaat, ada juga potensi yang merugikan dari penggunaan situs-situs tersebut. Selain memunculkan ancaman terhadap privasi penggunanya, efek negatif yang dapat terjadi adalah pencemaran nama baik, penipuan, dan bullying. Indonesia juga menduduki peringkat kedua dengan kasus bullying tertinggi di dunia. Menurut hasil survei ciricara.com, aksi bullying di Indonesia cenderung lebih banyak dilakukan di media sosial (http://ciricara.com/2012/10/19/ indonesia-masuk-daftar-negara-dengankasus-bullying-tertinggi/).

Menanggapi kasus negatif penggunaan media sosial online, telah ada pihak-pihak yang melakukan berbagai upaya untuk meningkatkan literasi media digital di tengah masyarakat. Literasi media digital ini difokuskan kepada penggunaan media sosial. Upaya yang sebenarnya telah dimulai bertahun-tahun silam itu dilakukan dengan menggunakan berbagai pendekatan guna menuntaskan berbagai isu terkait dengan permasalahan digital media. Ada yang memakai pendekatan general, yaitu memberikan pembekalan literasi digital secara umum. Ada pula yang menggunakan pendekatan tematik, entah itu membidik konten tertentu seperti "anti-hoax", "internet security", atau berfokus pada cohort tertentu seperti "remaja" dan "anak-anak", atau tertuju pada segmen tertentu seperti "guru", "ibu rumah tangga". Meningkatkan level literasi publik, atau membuat masyarakat menjadi melek digital memang bukan tugas yang bisa diwujudkan melalui satu dua pendekatan saja.

Berdasarkan latar belakang di atas dapat diambil sebuah permasalahan pentingnya pemahaman literasi media sosial khususnya bagi mahasiswa. Mahasiswa sebagai kelompok usia muda atau remaja akhir berusia antara 18-20 tahun seringkali masih belum mandiri dan umumnya masih menjadi tanggungan 
keluarga (Sudarmanti dan Yusuf, 2016). Keberadaan gadget (smartphone) sebagai media komunikasi dan akses internet menjadi kebutuhan terpenting bagi mereka. Dengan kurangnya pemahaman tentang literasi media sosial akan menjadikan mereka berdampak melakukan kesalahan dalam menggunakan media sosial dewasa ini.

Penelitian tentang literasi media dan pemantauan media tumbuh di Indonesia dengan kekhasan modelnya masingmasing telah dikaji oleh delapan lembaga yang telah melakukan gerakan literasi media dan media watch sejak tahun 2009 hingga kini. Kedelapan lembaga tersebut adalah KIPPAS di Medan, Yayasan Sahabat Cahaya dan Remotivi di Jakarta, LeSPI di Semarang, Jurnal Celebes di Makassar, serta MPM, ECCD-RC, dan Centre for LEAD di Yogyakarta (Poerwaningtias, dkk. 2013). Kajian dan penelitian ini telah dijelaskan dalam buku tentang model-model literasi media dan media watch yang ada.

Menariknya penelitian ini dilaksanakan pada mahasiswa ilmu komunikasi Unsoed karena berasal dari berbagai suku yang ada di Indonesia khususnya dari Suku Sunda, Betawi, Sumatera, Irian, Sulawesi, dan lainlain dengan berbagai lapisan masyarakat yang kesemuanya menggunakan media sosial. Yang ingin diketahui dari penelitian ini untuk menggambarkan dan menganalisis pemahaman mahasiswa dalam hal literasi media yang berdampak pada mahasiswa komunikasi karena merekalah yang seharihari menggunakan media komunikasi baik secara teoritis dalam pembelajaran dan praktis sehari-hari.
Penelitian lain tentang Literasi Media bagi mahasiswa sudah banyak yang melakukan diantaranya Literasi Media Pada Mahasiswa Prodi Ilmu Komunikasi Universitas Mulawarman oleh Inda Fitryarini (2016) dengan hasil penelitiannya. Relasi remaja dengan media massa telah menjadi persoalan yang problematik. Di satu sisi media adalah sarana transformasi ide, nilai, norma, dan transformasi mental ke arah penyadaran, pencerahan, dan kemajuan kehidupan. Di sisi lain media massa menularkan pengaruh buruk yang mendegradasi format kemanusiaan dan kemampuan berpikir remaja. Dampak buruk media massa tersebut, melahirkan gagasan yang disebut media literacy. Tujuan penelitian tersebut adalah untuk menggambarkan tahapan literasi media di kalangan sembilan remaja Prodi Ilmu Komunikasi FISIP Universitas Mulawarman.

Untuk mencapai tujuan tersebut, peneliti menggunakan metode kualitatif deskriptif. Data primer diperoleh melalui wawancara semistruktur dan observasi sedangkan data sekunder diperoleh melalui dokumentasi dan literatur. Teknik sampling yang digunakan dalam penelitian ini adalah purposive sampling. Dari hasil pembahasan dapat disimpulkan bahwa literasi media di kalangan sembilan remaja Prodi Ilmu Komunikasi Angkatan 2014 adalah berada pada tahapan awal. Pada tahap ini audiens memiliki kemampuan berupa pengenalan media, terutama efek positif dan negatif yang potensial diberikan oleh media. Pada penelitian Inda Fitriyani (2016) ini hanya ingin memberikan pengambaran saja dari sembilan remaja sebagai infromannya. 
Sementara penelitian Literasi Media Digital Mahasiswa Universitas Muhammadiayah Bengkulu (2016) yang dilakukan oleh Juliana kurniawati dengan hasil penelitian ini mengungkapkan bahwa: 1). Pemahaman mahasiswa Universitas Muhammadiyah Bengkulu mengenai media digital berada pada kategori sedang, 2). Tingkat individual competence mahasiswa Universitas Muhammadiyah Bengkulu dalam meliterasi media digital berada dalam level basic, 3). Faktorfaktor yang mempengaruhi tingkat individual competence terkait literasi media digital terutama adalah faktor lingkungan keluarga. Pada penelitian yang dilakukan oleh Juliana Kurniawati ini tidak jauh berbeda penelitian yang dilakukan oleh Inda Fitriyani, yang membedakannya ingin melihat faktor yang mempengaruhi mahasiswa dalam meliterasi media dan penelitian yang dilakukan ini selain untuk melihat pemahaman dan dampak yang ditimbulkan oleh literasi media.

Hasil penelitian terdahulu tentang Literasi Media Internet di Kalasilangan Mahasiswa oleh Gracia Rachmi Adiarsi, Yolanda Stellarosa, Martha Warta Silaban (2015) menyatakan bahwa siswa yang mengakses internet di bawah lima jam per hari sudah sibuk dengan pekerjaan dan tidak terlalu intens dalam menggunakan internet baik melalui smartphone atau komputer. Temuan berbeda muncul dari para siswa yang mengakses internet lebih dari lima jam per hari. Sebagian besar waktu, mereka menggunakan internet untuk media sosial dan pesan instan (instant messenger) melalui smartphone. Sikap kritis terhadap pesan media tergantung pada minat informan terhadap informasi. Penelitian Gracia dan kawan-kawan (2015) lebih menekankan pada durasi waktu penggunaan internet oleh mahasiswa dengan membandingkan dengan durasi waktu dengan penggunaan internet oleh siswa. Tetapi dalam penelitian yang dilakukan ini menekankan pada dampak yang ditimbulkan oleh penggunaan media sosial.

Kemajuan teknologi dewasa ini telah menawarkan bongkahan sumber-sumber atau resources informasi dan komunikasi amat luas yang pernah dipunyai oleh umat manusia. Mahluk hidup yang normal seperti manusia selalu membutuhkan informasi untuk menjaga kelangsungan hidupnya, dan untuk mendapatkan informasi tersebut manusia perlu berkomunikasi dengan manusia lain. Kemajuan teknologi komunikasi dan informasi yang sedemikian pesatnya saat ini menjadikan informasi sangat berlimpah dan seolah-olah tidak mempunyai batas lagi, dan penggunaannyalah yang tinggal memilah dan memilih mana informasi yang dikategorikan sebagai sampah dan mana informasi yang dibutuhkan untuk kehidupan mereka(Istiyanto, 2015).

Menurut Nasution (2004: 3) dunia sedang berubah, bentuk masyarakat yang seperti apa yang kelak muncul sebagai hasil dari gerak perubahan ini diramalkan oleh berbagai ahli seperti yang disebutkan oleh Wizard (1982) di antaranya George Lichtein yang menyebut masa yang baru ini sebagai post-bourgeois; Ralph Dahrendorf menggunakan istilah post-capitalism; Amitai Etzioni menjuluki post-modern; sedangkan Kenneth Boulding memakai 
istilah post-civilized, namun dalam hal popularitas istilah yang diajukan sosiolog Harvard, Daniel Bell, menyebutnya dengan istilah masyarakat post-industrial.

Inti dari perkembangan teknologi komunikasi dan informasi seperti yang diungkap oleh para ahli di atas menurut Istiyanto (2015) adalah terjadinya perubahan sosial yang menimpa manusia sebagai pengguna aktif perkembangan teknologi tersebut. Perubahan tersebut dapat bernilai positif ketika teknologi komunikasi digunakan sesuai dibutuhkan, sebaliknya ketika semua perkembangan teknologi komunikasi tersebut digunakan tidak sesuai kebutuhan dan bahkan cenderung memberikan pengaruh buruk maka dapat dikatakan itu sebagai dampak negatif perubahan.

Salah satu perubahan teknologi komunikasi yang terlihat membawa perubahan sosial secara masif adalah keberadaan internet. Internet menurut (Sudarmanti dan Yusuf, 2016) adalah sarana yang memungkinkan suatu informasi dipertukarkan dan dikomunikasikan melalui jaringan komputer yang saling berhubungan. Pada perkembangannya media komputer ini beralih menjadi media baru dengan munculnya banyak teknologi elektronik dan media baru yang sebelumnya belum ada seperti telepon seluler.

Penggunaan teknologi elektronik semakin memungkinkan semua penggunanya berhubungan dengan cepat. Karenanya kehadiran media baru juga mengalami perkembangan signifikan. Bermunculan wahana media sosial seperti Twitter, Facebook, Path,
Line, What's Up, dan sebagainya. Media ini dikenal sebagai media sosial karena memberi peluang setiap orang melakukan jejaringan sosial dan berbagi informasi. Pesan informasi melalui media sosial dengan jejaring internet ini disusun dan dikemas sedemikian rupa agar tersampaikan secara lebih efektif (Sudarmanti dan Yusuf, 2016).

Jejaring sosial menurut Aras (2016) adalah struktur sosial yang terdiri dari elemen-elemen individuil atau organisasi. Jejaring ini menunjukkan jalan dimana mereka berhubungan karena kesamaan sosialitas, mulai yang dikenal seharihari sampai dengan keluarga. Istilah ini dikenalkan oleh Profesor JA. Barnes di tahun 1954 yang umumnya berfungsi sebagai jalinan pertemanan dalam dunia maya melalui situs jejaring sosial (Aras, 2016).

Beberapa situs layanan jejaring sosial berbasis website menyediakan fasilitas yang seragam bagi pengguna untuk dapat berinteraksi seperti chat, messaging, email, video, chat suara, share file, blog, diskusi grup, dan sebagainya. Umumnya jejaring sosial ini memberikan layanan untuk membuat biodata diri pengguna. Di sinilah ketika literasi media tidak bijak sangat memungkinkan terjadinya penyimpangan dan motivasi kejahatan dalam penggunaan media sosial tersebut. Mulai dari penipuan, penculikan, kejahatan seksual dan pornografi, hingga kekerasan fisik setelah penggunanya melakukan pertemuan langsung.

Media sosial adalah media untuk interaksi sosial, menggunakan teknik komunikasi yang sangat mudah diakses. Media sosial kini sudah menjadi bagian 
kehidupan sehari-hari pengguna internet di Indonesia karena situs yang paling sering dikunjungi. Pengguna internet pada umumnya menggunakan waktu terbanyak online untuk berkomunikasi melalui media sosial, seperti Facebook, Twitter, Ask.fm dan lain-lain (Triastuti, dkk. 2017).

Media sosial juga dapat memfasilitasi perubahan. Media sosial adalah sebuah media online, dengan para penggunanya bisa dengan mudah berpartisipasi, berbagi, dan menciptakan isi meliputi blog, jejaring sosial, wiki, forum dan dunia virtual. Blog, jejaring sosial dan wiki merupakan bentuk media sosial yang paling umum digunakan oleh masyarakat di seluruh dunia. Pendapat lain mengatakan bahwa media sosial adalah media online yang mendukung interaksi sosial dan mengubah komunikasi menjadi dialog interaktif. Jejaring sosial merupakan situs dimana setiap orang bisa membuat web page pribadi, kemudian terhubung dengan teman-teman untuk berbagi informasi dan berkomunikasi.

Jika media tradisional menggunakan media cetak dan media broadcast, maka media sosial menggunakan internet. Media sosial mengajak siapa saja yang tertarik untuk berpartisipasi dengan memberi kontribusi dan umpan balik secara terbuka, memberi komentar, serta membagi informasi dalam waktu yang cepat dan tidak terbatas. Saat teknologi internet dan handphone makin maju, maka media sosial pun ikut tumbuh dengan pesat. Kini untuk mengakses Facebook atau Twitter misalnya, bisa dilakukan dimana saja dan kapan saja hanya dengan menggunakan handphone.
Demikian cepatnya orang bisa mengakses media sosial mengakibatkan terjadinya fenomena besar terhadap arus informasi tidak hanya di negara-negara maju, tetapi juga di negara berkembang seperti di Indonesia. Karena kecepatannya, media sosial juga mulai tampak menggantikan peranan media massa konvensional dalam menyebarkan berita-berita.

Perkembangan media sosial saat ini juga dikarenakan semua orang yang sudah bisa memiliki media sendiri. Jika untuk memiliki media tradisional seperti televisi, radio, atau koran dibutuhkan modal yang besar dan tenaga kerja yang banyak, maka lain halnya dengan media sosial. Seorang pengguna media sosial bisa mengakses menggunakan media sosial dengan jaringan internet bahkan yang aksesnya lambat sekalipun, tanpa biaya besar, tanpa alat mahal dan dilakukan sendiri tanpa karyawan. Seseorang sebagai pengguna media sosial dengan bebas bisa mengedit, menambahkan, memodifikasi baik tulisan, gambar, video, grafis, dan berbagai model konten lainnya. Bila dalam menggunakan media sosial asal-asalan atau bahkan menyinggung pihak-pihak lain maka akan sangat beresiko secara hukum positif di Indonesia. Karena itu, memahami literasi media dengan baik serta kemampuan menggunaka medai sosial dengan bijak menjadi sangat dibutuhkan oleh semua pengguna termasuk mahasiswa.

Perkembangan teknologi komunikasi melalui internet yang sedemikian rupa membawa tidak saja dampak positif namun juga sekaligus dampak negatif yang menyertainya. Muncul banyak kejahatan 
yang bersumber dari penyalahgunaan media komunikasi terbaru ini. Para pengguna yang tidak mengenal batas umur, meskipun dalam sejarah penciptaannya memang tidak ditujukan untuk anak-anak di bawah umur, akan sangat berbahaya bila tidak bijaksana dalam menggunakannya. Di sinilah diperlukan pengetahuan dan pemahaman akan literasi media yang akan menjadi benteng terdepan untuk menyeleksi dampak negatif penggunaan media sosial.

Potter (2011) menyatakan bahwa literasi media adalah seperangkat perpektif yang kita gunakan secara aktif saat mengakses media massa untuk menginterpretasikan pesan yang kita hadapi. Literasi media bagaimana khalayak dapat mengambil kontrol atas media. Literasi media merupakan skill untuk menilai makna dalam setiap jenis pesan mengorganisasikan makan itu sehingga berguna, dan kemudian membangun pesan untuk disampaikan kepada orang lain.

Literasi media digital atau sering disingkat menjadi literasi media saja adalah konsep penggunaan media dengan bijak dan sesuai kebutuhan (Angeliqa, 2016). Menurut Poerwaningtias, dkk (2013:16) literasi media hadir sebagai benteng bagi khalayak agar kritis terhadap isi media, sekaligus menentukan informasi yang dibutuhkan dari media. Ia akan mendorong pengguna untuk kritis mempertanyakan apa yang ada di balik isi media yang diaksesnya. Literasi media ini bisa bersumber kepada dirinya sendiri untuk selalu menanyakan mengapa, kenapa dan bagaimana. Juga bisa bersumber dari keterbukaannya kepada orang lain dalam menggunakan media sosial melalui proses komunikasi interaktif yang seimbang dan saling memberi.

Potter (2011) menyatakan bahwa literasi media adalah seperangkat perspektif yang digunakan secara aktif saat mengakses media massa untuk menginterpretasikan pesan yang dihadapi. Literasi media memberikan panduan tentang bagaimana mengambil kontrol atas informasi yang disediakan oleh media. Semakin media literate seseorang tinggi, maka semakin mampu orang tersebut melihat batas antara dunia nyata dengan dunia yang dikonstruksi oleh media.

Proses komunikasi sendiri merupakan hal yang gampang-gampang susah dilakukan, termasuk bagi para mahasiswa. Sebagai manusia dalam rentang remaja akhir menjelang dewasa yaitu sekitar usia 18 - 20 tahun kecenderungan mahasiswa untuk melakukan segala sesuatu secara mandirikurang diimbangi dengan kewaspadaan akan dampak negatif atau akibat perbuatannya. Mahasiswa seringkali kurang terbuka dan menganggap privasi adalah segalanya. Demikian juga dalam penggunaan media sosial bagi mereka. Kecenderungan untuk menjaga privasi menjadikan mereka menghindari membicarakan apa yang terjadi dalam setiap akses di media sosial, apakah itu mempunyai pengaruh buruk atau tidak baginya. Kewaspadaan menjadi sesuatu yang kurang diperhitungkan dalam setiap akses informasi di media sosial. Akibatnya, dampak yang akan menimpa menjadi semakin besar dan mempengaruhi. Pemahaman literasi media dengan baik menjadi kunci solutif yang tepat dalam menggunakan semua media sosial yang diakses. Penelitian ini mendukung kebijakan pemerintah tentang literasi digital yang 
disampaikan oleh Kominfo pada 16 agustus 2018. Penelitian ini bertujuan menemukan model literasi media sosial digital dikalangan Mahasiswa FISIP Unsoed Purwokerto.

\section{Metode Penelitian}

Penelitian ini menggunakan pendekatan kualitatif dan fokus penelitian ini untuk pemilihan informan dilakukan dengan cara sengaja (purposive sampling), yakni peneliti memilih informan, dalam hal ini adalah para mahasiswa Jurusan Ilmu Komunikasi FISIP Unsoed yang menggunakan media sosial secara aktif sejumlah 23 orang mahasiswa berbagai angkatan (2014-2016) yang aktif kuliah. Adapun teknik pengumpulan data yang digunakan meliputi: wawancara mendalam (In-depth Interview), Focus of Group Discussion (FGD), analisis dokumentasi, teknik analisis data.

Pelaksanaan wawancara secara mendalam dilakukan oleh tim peneliti kepada informan secara tatap muka dan bila perlu menggunakan media interaktif seperti Line dan Whatsapp. Sementara FGD dilakukan dalam dua periode dikarenakan mahasiswa aktif sehingga dibagi dalam dua kelompok diskusi. Untuk analisis dokumentasi digunakan sebagai pelengkap dan pembanding data yang dikumpulkan sebagai data sekunder dari berbagai sumber baik cetak maupun elektronik.

Untuk menguji kemantapan dan keabsahan data yang telah berhasil dikumpulkan, penelitian ini menggunakan teknik triangulasi data. Menurut Patton, triangulasi data adalah usaha membandingkan dan mengecek balik derajat kepercayaan suatu informasi yang diperoleh melalui waktu dan alat yang berbeda dalam metode kualitatif (dalam Moleong, 2000: 330). Dalam penelitian ini, peneliti menggunakan triangulasi metode. Adapun cara-cara yang telah dilakukan adalah; membandingkan data hasil FGD dengan hasil wawancara dan membandingkan hasil wawancara dengan isi suatu dokumen yang terkait.

\section{Hasil Penelitian dan Pembahasan}

\section{Pemahaman Mahasiswa Tentang Dampak Negatif Media Sosial}

Salah satu kunci pengetahuan untuk menggunakan 'sesuatu' adalah mengerti akan dampak negatif dari 'sesuatu' tersebut. Karena setelahitupelakuatau pengguna akanmembuat keputusan apakah 'sesuatu' dapat diteruskan digunakan atau justru ditinggalkan. Demikian pula dengan media sosial, sebagai sebuah media baru yang sedang menjadi tren dan kebutuhan masyarakat informasi menjadikan media sosial sangatlah dipentingkan dan diutamakan. Apalagi bagi mahasiswa yang notabene akan terus menjadikan sebagai sarana untuk mendapatkan pertemanan baru atau mencari yang lama, bertukar segala informasi dari yang remeh hingga yang penting, dan alasan eksistensi di media online.

Secara subtansi sebenarnya, mahasiswa sudah melek media (literasi media) juga sudah mengetahui akan dampak yang ditimbulkan dari media sosial tersebut baik dampak negatifnya maupun dampak positifnya. Menjadi penting untuk diketahui apakah para informan dari mahasiswa ini mengetahui lebih detail dampak dan perilaku buruk yang dihasilkan akibat penggunaan media sosial bagi mereka. Beberapa infoman menyebutkan dalam kegiatan FGD seperti berikut ini: 
"Saya mengetahui dampak negatif yang terjadi ketika saya mengakses media sosial, otomatis saya mengakses internet dan saya diawasi oleh mata yang melihat ke dalam teknologi terutama ketika mereka mengakses media sosial yang sama. Jika saya melakukan self disclosure di dalam media sosial itu berlebihan akan menimbulkan dampak yang tidak terduga, contohnya: saya update mengenai diri saya sedang berada dimana atau upload foto saya yang berada di suatu tempat yang saya kunjungi di Instagram otomatis jika orang ingin berbuat jahat kepada saya mereka bisa melacak saya berada dimana dan menculik saya atau hal-hal yang kita tidak fikirkan sebelumnya. Dampak negatif lainnya jika kita mengakses media sosial timbulnya rasa gengsi, rasa ingin menjadi seperti orang lain, dan konsumtif dalam hal berpakaian, kuliner, makeup, dan lain-lain. Karena saya yakin seseorang yang mengakses media sosial jarang upload tentang dirinya ketika sedang kesulitan kebanyakan dari pengguna sendiri pasti post foto tentang momen-momen bahagia mereka. Contohnya: saya sebagai pengguna sosial perempuan saya melihat selebgram, artis, atau teman saya yang lain ketika dia berpakaian bagaimana dan berdandan bagaimana jika cocok dengan karakter saya,saya pasti mencari apa yang mereka gunakan" (Annisa F, angkatan 2015).

"Menurut saya, dampak negatif dari media sosial adalah kecanduan. Seringkali kita menundanunda pekerjaan dan lebih memilih untuk menggunakan media sosial tersebut. Tidak hanya itu, media sosial juga sering memuat konten negatif dan hoax sehingga menjadi korban cybercrime" (Ichtiarin, angkt 2014).

"Isu SARA yang mudah mencuat. Diantara banyaknya pengguna sosial media di Indonesia saja, tentu banyak orang yang masih memanfaatkan media sosial sebagai media yang digunakannya untuk memprovokatorkan konten yang bersifat SARA, contohnya yang pernah saya lihat ialah isu Ahok yang tidak pantas maju menjadi gubernur DKI dikarenakan ia dari golongan Chinese serta non muslim sehingga dianggap tidak mampu mewakili masyarakat Jakarta.Isu Pornografi yang mudah tersebar di berbagai kalangan. Media sosial dengan power-nya yang kuat mampu menyebarkan satu isu pada khalayak, termasuk pornografi. Contohnya saja, baru-baru ini tersebar isu video porno yang dianggap milik mahasiswa UI di kalangan mahasiswa laki-laki. Penyebarannya pun melalui media sosial LINE Group. Hal ini mampu memberikan efek negatif bagi pelaku dalam video porno serta bagi orang-orang yang menontonnya.Membuat orang menjadi malas. Dengan terus kecanduan mengakses media sosial, seseorang bisa menjadi malas dalam mengerjakan apapun di kehidupan nyatanya, atau dengan kata lain menjadi kurang produktif, seperti dalam mengerjakan tugas kuliahnya" (Hesti, angkatan 2014).

Seperti yang disampaikan di atas tadi, secara umum informan sudah mengetahui dampak negatif yang mungkin terjadi dari penggunaan media sosial yang mereka akses. Baik yang berdampak secara pribadi karena menjadi pemalas, menunda-nunda pekerjaan atau kuliah, kecanduan sehingga tidak mementingkan hal penting lainnya, menjadi individualis, menjadi konsumtif hingga dampak buruk lainnya yang cakupan permasalahannya lebih luas seperti isu politik nasional, SARA, penipuan informasi atau hoax, pornografi, penipuan data, penculikan, cyberbullying, body shaming, pemerkosaan, dan masih banyak lagi.

Bila dihubungkan dengan adanya kasus-kasus penyimpangan yang terjadi dalam penggunaan media sosial, informan menjawab dalam wawancara penelitian dan proses FGD seperti di bawah ini:

"Ada, yang banyak saya amati yaitu penyimpangan berbau sara dan pornografi. Contoh SARA: media sosial sangat sensitif isu SARA. Menurut saya hal ini apabila di-posting di media sosial akan menjadi perdebatan yang sangat panjang dan dapat dijadikan sebagai adu domba. Postingan-postingan di Line dan Facebook terutama sering saya temui yaitu tulisan yang sensitif isu SARA. Contoh pornografi: banyak iklan berbau pornografi baik itu dalam bentuk game atau yang lain yang bisa kita temui tanpa perlu mencarinya ketika kita sedang membuka laman tertentu. Hal ini tentu sangat tidak baik karena saat ini banyak anak kecil dan remaja yang mengakses media sosial dan dapat terpapar oleh hal-hal berbau pornografi.Video porno dan konten porno yang lainnya dapat dengan sangat mudah disebarkan dan diakses melalui media sosial seperti kasus video porno yang belakangan ini viral karena mengatas namakan sebagai Mahasiswa UI. Kabar tersebut viral di berbagai media sosial 
baik Instagram, Line, Twitter dan terutama Youtube. Hal ini tentu berbahaya bagi anakanak dan remaja karena ketika berita tersebut banyak diperbicangkan di media sosial dan menjadi trending pertama pada Youtube, anakanak dapat menjadi penasaran dan melihat hal yang sangat buruk tersebut, hal yang seharusnya tidak menjadi konsumsi publik. Contoh perjudian : perjudian biasanya banyak terjadi di game online, namun untuk kasusnya saya kurang mengetahui karena saya pribadi tidak suka bermain game hehehe" (Farah, angkatan 2015).

"Oknum yang menyalahgunakan untuk hal negatif, karena mudah membuka berbagai hal lewat social media jadi membuka situs pornografi. Banyak yang menyebarkan konten yang memprovokasi pihak-pihak tertentu yang biasanya sensitif (SARA) sehingga memicu konflik publik. Game online yang ada juga mengarah pada perjudian, atau kasus kekerasan yang banyak terjadi karena mudahnya membuka situs video kekerasan dan dicontoh atau terpengaruh" (Supriyatin, angkatan 2015).

Secara umum keseluruhan informan memahami adanya dampak buruk akibat media sosial. Dampak buruk tersebut bisa berefek secara pribadi yang berimbas secara sosial. Mereka juga memahami adanya penyimpangan penggunaan media sosial yang ada dari oknum-oknum yang tidak bertanggung jawab dalam memanfaatkan media sosial dengan tujuan negatif dan menyimpang.

Pemahaman informan akan dampak negatif dan penyimpangan yang muncul akibat dari penggunaan media sosial tidak berarti mereka meninggalkan untuk menggunakan media tersebut. Mereka hanya menjadi lebih waspada dan berhati-hati. Seperti diungkap oleh beberapa informan dalam wawancara mendalam di bawah ini:

"Tentunya sebagai seorang mahasiswa kita harus pandai dalam menggunakan media sosial. Manfaatkan kemajuan teknologi dan keberadaan media sosial. Namun, jangan sampai kita yang diperbudak oleh teknologi. Cerdaslah dalam menggunakan media sosial. Jangan mudah percaya dengan apa yang kita lihat, dan apa yang kita baca di media sosial. Dalam hal ini literasi media diperlukan untuk memfilter informasi" (Nida, angkt 2014).

"Yang harus dilakukan mahasiswa untuk menghindari dampak negatif dari media sosial yaitu dengan mengurangi waktu penggunaan media sosial. Apabila sedang berada di rumah atau sedang bersama keluarga sebisa mungkin menggunakan media seperlunya saja. Selain itu membatasi media sosial yang digunakan, tidak perlu semua media sosial digunakan" (Elzha, angkatan 2014).

"Selama ini saya berusaha untuk menggunakan media sosial secara bijak. Memilah dan memilih apa yang perlu dan tidak perlu saya tonton, lihat, dan ikuti. Saya juga berusaha menggunakan media sosial secara secukupnya saja. Kemudian mengingat maraknya kejahatan di media sosial, saya berusaha untuk tidak terlalu terbuka di media sosial. Sebagai mahasiswa yang sudah mengetahui dampak negatif media sosial, saya harus berusaha untuk mengedukasi orang-orang di sekitar saya misalnya dalam lingkup terkecil yaitu keluarga dan teman untuk, menghindari hal-hal buruk di media sosial" (Inadha, angkatan 2015).

Informan telah memahami adanya dampak negatif yang bisa ditimbulkan oleh penggunaan media sosial, karena itu mereka telah melakukan berbagai cara untuk menekan munculnya dampak negatif yang mungkin mengenai diri mereka. Upaya tersebut ada yang bersifat pribadi yaitu dengan mengurangi waktu penggunaan media sosial, memilih dan memilah mana media sosial yang mereka butuhkan, hingga mencoba memberika edukasi pada orangorang terdekat di sekitar mereka.

Berdasarkan hasil pengumpulan data yang telah dilakukan dalam penelitian kepada para informan dapat digambarkan bahwa mereka menyadari dan mengetahui penggunaan media sosial yang mereka lakukan itu mempunyai dampak negatif dan penyimpangan perilaku yang dapat terjadi sewaktu-waktu bagi mereka. Dampak 
tersebut bisa bersifat pribadi seperti menerima dan menyebarkan berita bohong (hoax), kecanduan, berpola konsumtif, hingga berefek negatif yang berskala lebih luas seperti penipuan data, penculikan, cyber bullying, body shaming, pemerkosaan, pornografi sampai kekerasan.

Pendapat yang menyatakan bahwa kehadiran media sosial dalam internet sebagai akibat dari kebebasan informasi yang mudah diakses ini mempunyai pengaruh negatif telah disampaikan oleh Amrullah (2016) dalam uraiannya bahwa informasi yang sangat mudah didapatkan memang memberikan pengetahuan lebih kepada penggunanya. Tetapi terkadang informasi malah memberikan pengaruh buruk (karena luasnya informasi dan perspektif orang-orang yang tidak dapat dikontrol).

Banyaknya informasi yang salah dipersepsikan dapat menjurus ke hal-hal seperti penyimpangan perilaku sosial, misalnya: berubahnya gaya hidup menjadi hedonis (lifestyle modern yang marak ditunjukkan oleh media dimana kesenangan dan kemewahan adalah hal utama), tidak mempedulikan agama lagi bahkan menjadi atheis (karena manusia yang terpengaruh oleh ajaran-ajaran modern baru), cyber-crime (kejahatan dalam dunia maya dengan media internet yang dapat berdampak besar dalam dunia nyata), dan beberapa penyimpangan moralitas atau psikologis (Amrulah, 2016).

Lebih jauh diungkap oleh Amrulah (2016) bahwa media-media sekarang cenderung memberikan konten-konten yang memanjakan khayalan masyarakat, seperti kehidupan yang mewah dan berfoya-foya, pergaulan bebas ala "orang Barat", dan lain-lain. Media sekarang sangat jarang memberikan konten edukatif, namun di sisi yang sama masyarakat pun ternyata lebih senang dengan konten kehidupan modern tersebut. Seperti kondisi yang saling terikat kebutuhan akan media baru ternyata sejalan dengan kebutuhan masyarakat penggunanya.

Media juga memberikan pandangan-pandangan baru, prinsip-prinsip, kepercayaan, dan budaya baru yang bertolak belakang dengan apa yang negara miliki. Pandangan, prinsip, kepercayaan, dan budaya yang terpengaruh modernisasi, semakin menjauhkan kepribadian dan identitas asli Warga Negara Indonesia, terutama identitas negara yang beragama, bermoral, bermartabat, dan memiliki normanorma yang konservatif serta gaya hidup sederhana sudah semakin dilupakan. Tidak hanya itu saja, media modern dan didukung oleh teknologi yang canggih dan memadai, juga memancing maraknya cyber-crime, penyimpangan moral dan psikologis, juga efek lain yang berbahaya (Amrulah, 2016).

Informan secara umum, selain mengetahui adanya dampak negatif media sosial mereka juga mengetahui cara-cara yang dianggap dapat untuk menangkal dampak negatif yang dapat terjadi dari penggunaan media sosial yang khusus berguna untuk dirinya sendiri, seperti: membagi waktu penggunaan media sosial sesuai kebutuhan untuk menghindari kecanduan, dan pola konsumtif, tidak menunda pekerjaan yang lebih utama/penting bagi mereka, lebih berhati-hati menerima informasi, melakukan cross check data (konfirmasi) kepada sumber yang lebih kuat, menolak sedari awal informasi yang dianggap mengganggu seperti penipuan, pornografi dan 
kekerasan (cyber bullying). Selain itu juga ikut terlibat menyebarkan kesalahan akibat dampak negatif penggunaan media sosial seperti ada di antara informan juga ikut berperan aktif dalam mengendalikan diri dan lingkungannya untuk tidak terkena dampak negatif penyimpangan dalam penggunaan media sosial seperti aktif dalam melakukan edukasi kepada orangorang di sekitar lingkungan terdekat mereka seperti keluarga dan teman-temannya. Satu hal yang tidak bisa dihindari oleh informan mahasiswa ini terutama informan mahasiswa yang mempunyai tingkat kehidupan yang lebih mapan yaitu perilaku yang hedonisme, terbukti dengan seringnya mereka gonta-ganti telepon genggam.

\section{Model Literasi Media Sosial Mahasiswa}

Melihat betapa rawannya penggunaan media sosial yang berdampak negatif kepada para penggunanya, telah diupayakan secara masif untuk meminimalisir akibat buruknya. Tindakan untuk menjadikan para pengguna media sosial cerdas dan bijak memakai media sosial sering disebut sebagai aktivitas literasi media atau literasi digital yang dihubungkan dengan media aksesnya.

Menurut Potter (2011) model literasi media ada empat faktor yang digunakan dalam literasi media yaitu yaitu struktur pengetahuan, lokus personal, kompetensi dan keterampilan, serta arus tugas pengolahan informasi. Potter mengatakan, "The foundation ofbuilding media literacy is a set of five strong knowledge structures. The foundational knowledge structures are media effects, media content, media industries, the real world, and the self" (2011: 33). Model literasi media yang dijelaskan oleh Potter ini
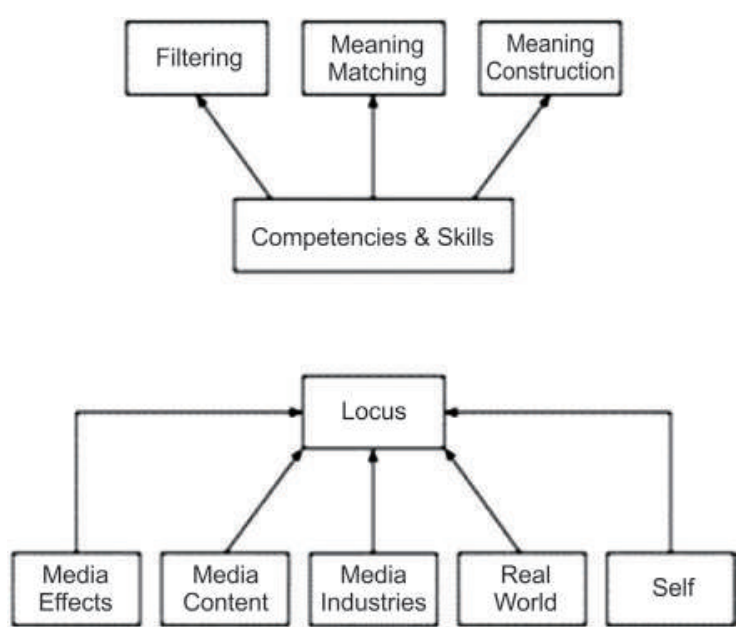

Gambar 1. The Cognitive Model of Media Literacy (Sumber: Potter, 2011)

sering disebut dengan 'The Cognitive Model of Media Literacy', seperti dalam gambar 1 .

Mahasiswa sebagai insan pembelajaran aktif tentu saja sangat terkait dengan aktivitas literasi media tersebut. Selain sangat berhubungan dengan perilaku aktif dalam menggunakan media sosial, mereka merupakan ujung tombak nyata adanya pengaruh penggunaan media sosial baik secara positif dan negatif dalam aktivitas sehari-hari mereka. Maka pada indikator competency dan skill di model Literasi Media oleh Potter, informan mahasiswa sudah melek media. Di antaranya informan yang berpendapat adalah Elva, angkatan 2014; yang mengatakan

"Literasi media yaitu bagaimana kita bisa mengkases, memahami, menganalisis, menyebarluaskan informasi yang ada di media. Sehingga konsumen media menjadi melek media. Namun juga konsumen media haruslah bijak dalam mengonsumsi informasi yang ada di media sosial"

"Literasi media menurut saya adalah pemahaman seseorang dalam menganalisis suatu konstruksi yang dibuat oleh media. Media membuat suatu agenda publik untuk dikonsumsi oleh publik sehingga publik membicarakan isu tersebut. Literasi media yang kita punya akan dapat memahami isi dari media yang kita baca" (Ivan, angkatan 2014). 
"Yang saya tahu tentang literasi media adalah bagaimana seseorang berfikir secara kritis bagaimana media tersebut dibuat,dikontruksi dan digunakan untuk banyak orang. Apakah media itu benar-benar murni untuk berkomunikasi atau hanya untuk kepentingan lain. Literasi media pun dapat membuat seseorang melek atau peka terhadap hal kecil yang ada disekitar kita" (Zahra, angkatan 2016).

Secara umum informan yang merupakan mahasiswa aktif mengetahui pentingnya literasi media untuk menambah kehatihatian dan tingkat kewaspadaan mereka. Dapat digambarkan informasi tersebut bersumber dari hasil wawancara dan observasi penelitian di bawah ini:

"Yang saya ketahui tentang literasi media adalah sebuah keadaan dimana pengguna media telah menyadari sepenuhnya akan media yang tengah berkembang saat ini serta cerdas dan kritis dalam menyikapi informasi yang diberikan oleh media tersebut" (Salma, angkatan 2015).

Dari penjelasan informan saat diwawancarai dan FGD di atas dapat digambarkan bahwa mereka telah mengetahui apa itu literasi media dari tingkat yang sederhana hingga tingkat yang lebih luas. Secara teoritis tingkatan literasi media secara umum dapat dibagi menjadi tiga bagian yaitu; (1) Tingkatan awal, (2) Menengah, dan

Tingkatan Lanjut. Masih model Literasi Media oleh Potter pada indicator lokus dengan komponen-komponennya yang kelima tersebut pemahaman akan pentingnya, manfaatnya, efeknya, content dari pada real world-nya literasi media ini pun telah mereka jelaskan dalam hasil penelitian berikut ini:

"Kita jadi tidak dibodohi oleh media oleh kepentingan-kepentingan khususnya politik. Contoh kasus ada teman saya di Facebook dia mem-posting berita tentang hutang Indonesia dan kegagalan pemerintah namun bukan dari website atau portal berita yang jelas sebagai sumber berita. Lalu saya tanya dengan komentar di statusnya "ini sumber beritanya ko ga ada di stream media atau di website bank dunia atau BI sebagai bak central" setelah beberapa menit komontar saya tidak dijawab dan postingan tersebut dihapus" (Jaka, angkatan 2014).

"melalui literasi media ini kita bisa meningkatkan intelektual dengan aktif mencari informasi yang sesuai dengan kebutuhannya berdasarkan referensi yang ada, sehingga informasi yang didapat bisa menjawab kebutuhan yang dicari. Agar lebih mengetahui bagaimana mengakses memilih program yang bermanfaat dengan sesuai kebutuhan yang ada" (Siti, angkatan 2014).

"Manfaat dari memahami literasi media adalah kita bisa menjadi lebih kritis dalam melihat fenomena-fenomena yang diberitakan oleh media, dan kita menjadi tahu kebenaran yang sesungguhnya dengan pengetahuan literasi yang kita punya. Selain itu manfaat memahami literasi media yang lainnya adalah kita bisa mempunyai sikap tersendiri terhadap isu yang sedang beredar di masyarakat" (Ivan, angkatan 2014).

"Manfaat yang bisa saya dapatkan yaitusaya bisa mulai belajar, berfikir dan bertindak secara kritis tentang informasi yang saya terima atau media apa yang tengah digunakan. Bukan hanya itu saja kita pun menjadi melek terhadap media media yang ada sekarang ini” (Zahra, angkatan 2016).

Gambaran informan atas pentingnya literasi media ini menunjukkan bahwa mereka sadar akan pentingnya menghindari dampak buruk akibat penggunaan media sosial yang sering mereka lakukan. Upaya memininalisir dampak buruk dan penyimpangan yang mungkin timbul menjadikan informan mampu memilah langkah-langkah penggunaan media sosial secara benar dan sesuai kebutuhan, yang dimulai dari mengurangi waktu bermedia sosial, sampai memilih informasi yang seharusnya mereka ikuti atau tidak.

Literasimediasebenarnyamembutuhkan peranan aktif dari semua pihak. Literasi media tidak mungkin muncul dari para ahli media atau mereka yang menjadi korban saja, namun harus melebar ke semua lapisan. Hasil penelitian di bawah ini menunjukkan sejauh mana informan yang merupakan 
mahasiswa aktif dapat berkiprah dalam aktivitas literasi media ini. Apakah mereka masih memerlukan literasi media ini atau tidak, dan bentuk apa yang paling sesuai untuk menyebarkan pentingnya literasi media ini? Seperti diungkap dalam hasil wawancara dan FGD berikut ini:

"Walaupun mahasiswa sudah dianggap melek teknologi namun pemahaman mengenai literasi media masih sangat diperlukan karena walaupun mahasiswa sudah melek media namun mahasiswa khususnya orang Indonesia itu tidak kritis, gampang sekali mengonsumsi media dan lebih melihat ke salah satu sisi saja. Agar memahami literasi media, mahasiswa dapat melakukan hal hal yang kecil namun berdampak banyak contohnya sering membaca buku entah itu buku literatur atau tentang kehidupan sehingga pengetahuan mahasiswa tsb akan menjadi luas, menjadi ingin tahu akan banyak hal dan kemudian menjadi jiwa yang kritis. Disini mahasiswa juga diajak untuk menghapus stigma "ih bego banget sih, pertanyaan ga penting ditanyain." Karena bisa saja hal yang sebenarnya tidak masuk akal untuk dipertanyakan adalah hal yang malah seharusnya dikritisi" (Aulia, angkatan 2016).

"Perlu, karena bagaimanapun "kemelekan" mahasiswa akan teknologi tentu masih banyak hal yang belum diketahuinya. Sehingga pembelajaran literasi media masih tetap diperlukan. Bentuk kegiatan yang mampu dilakukan dalam mendukung pemahaman literasi mahasiswa ialah ceramah dalam kelas perkuliahan oleh dosen, seminar atau kuliah umum, serta kegiatan-kegiatan lain yang bersifat tatap muka" (Hesti, angkatan 2014).

"Menurut saya justru kondisi mahasiswa yang melek teknologi harus dibarengi dengan pemahaman tentang literasi media. Kegiatan yang bisa dilakukan misalnya seminar tentang pemanfaatan teknologi dan media. Topik tersebut sangat cocok dengan keadaan saat ini dan dapat menarik minat mahasiswa. Apalagi jika pengisinya adalah media enthusiast yang namanya sudah tidak asing di kalangan mahasiswa" (Inadha, angkatan 2015).

"Masih perlu, menurut saya walaupun mahasiswa, terkadang akun media sosial yang dimilikinya masih minim sekali di gunakan dengan maksimal. Acara seperti seminar yang bertemakan salah satu media sosial di bedah habis dan dapat digunakan apa saja dan bentuk penggunaaanya seperti apa saja" (Satria, angkatan 2014).
Informan telah menggambarkan posisi pentingnya literasi media ini bagi mereka dan umumnya pengguna media sosial secara umum. Mereka juga telah menunjukkan bentuk-bentuk kegiatan literasi media sesuai pendapat dan kebutuhan mereka sebagai mahasiswa. Dimulai dari usulan mewajibkan menjadi mata kuliah, aktif dalam kegiatan bertema literasi media seperti seminar, workshop, kampanye di media sosial juga sebagai kegiatan tandingan, pembuatan video yang dapat di-share di media online seperti Youtube, sosialisasi, dan beberapa kegiatan lain. Hal ini menunjukkan bahwa mereka memang membutuhkan pemahaman yang lebih tentang literasi media. Seperti diakui oleh Hesti dan Nidha yang menyebutkan tingkat literasi media bagi mahasiswa sangatlah beragam, ada yang sudah memahami dan ada yang masih rendah. Usulan kegiatan dan bentuk literasi media haruslah disesuaikan dengan kebutuhan mahasiswa agar literasi media dianggap penting dan sangat dibutuhkkan oleh informan secara khusus dan mahasiswa secara umum terlepas dari dampak negatif yang ditimbulkannya dan cara meminimalisirnya.

Literasi media digital atau sering disingkat menjadi literasi media saja menurut Angeliqa (2016) adalah konsep penggunaan media dengan bijak dan sesuai kebutuhan. Ia akan mendorong pengguna untuk kritis mempertanyakan apa yang ada di balik isi media yang diaksesnya. Sedangkan menurut Eshet (2002) menekankan bahwa literasi media digital seharusnya lebih dari sekedar kemampuan menggunakan berbagai sumber digital secara efektif. Literasi media digital juga 
merupakan sebentuk cara berpikir tertentu. Bawden (dalam Herlina, 2017) menawarkan pemahaman baru mengenai literasi media digital yang berakar pada literasi komputer dan literasi informasi. Sementara menurut Sulthan (2018) literasi media adalah tingkat pemahaman akan media daring dan media social.Literasi mediainibisa bersumberkepada dirinya sendiri untuk selalu menanyakan mengapa, kenapa dan bagaimana. Juga bisa bersumber dari keterbukaannya kepada orang lain dalam menggunakan media sosial melalui proses komunikasi interaktif yang seimbang dan saling memberi.

Dalam melihat pemahaman informan yang merupakan mahasiswa aktif pengguna media sosial ternyata mereka mengetahui apa itu literasi media dan bagaimana seharusnya mereka bersikap secara bijak dan cerdas dalam menggunakan media sosial ini. Informan secara umum juga telah mampu mengolah informasi yang mereka butuhkan, mewaspadai kesalahan informasi yang mereka dapatkan, mengecek dengan sumber yang lebih terpercaya, dan mendiskusikannya kepada pihak-pihak yang dianggap sesuai dengan bidang keahliannya atau teman yang dianggap lebih memahami sebuah informasi baru. Hal ini senada dengan pendapat dari Bawden (2001) yang menyebutkan bahwa digital media literasi lebih banyak dikaitkan dengan keterampilan teknis mengakses, merangkai, memahami dan menyebarluaskan informasi secara benar. Informan telah berproses mengenai literasi media yang terdiri dari serangkaian kompetensi komunikasi termasuk kemampuan mengakses, menganalisa, mengevaluasi dan mengkomunikasikan informasi dalam berbagai bentuk pesan tercetak dan tidak tercetak secara sesuai (The Alliance for a Media Literate America dalam Martin, 2008).

Secara aktif informan juga menjelaskan pentingnya pemahaman tentang literasi media ini disebarkan kepada mereka yang dianggap perlu mengetahuinya. Dari usulan pembahasan materi literasi media ini lewat perkuliahan atau menjadi minimal salah satu sesi materi dalam kelas tatap muka, hingga mengadakan bentuk kegiatan-kegiatan khusus yang lebih mampu mendidik masyarakat secara luas. Pilihan-pilihan kegiatan tersebut adalah seperti mengadakan seminar, workshop, kuliah umum, dan edukasi langsung dalam bentuk kampanye literasi media, pembuatan video yang disebar ke Youtube sehingga dapat diakses khalayak secara masif.

Kondisi yang dipunyai informan tersebut senada dengan pendapat dari Martin (2008) yang merumuskan beberapa dimensi literasi media digital seperti berikut:

1. Literasi digital akan melibatkan kemampuan aksi digital yang terikat dengan kerja, pembelajaran, kesenangan dan aspek lain dalam hidup sehari-hari.

2. Literasi digital secara individual bervariasi tergantung situasi sehari-hari yang ia alami dan juga proses sepanjang hayat sebagaimana situasi hidup individu itu.

3. Literasi digital dibentuk oleh namun lebih luas dari literasi teknologi komunikasi informasi.

4. Literasi digital melibatkan kemampuan mengumpulkan dan menggunakan pengetahuan, teknik, sikap dan kualitas personal selain itu juga kemampuan merencanakan, menjalankan dan mengevaluasi tindakan digital sebagai bagian dari penyelesaian masalah/tugas dalam hidup. 
5. Literasi digital juga melibatkan kesadaran seseorang terhadap tingkat literasi digitalnya dan pengembangan literasi digital.

Pendapat Martin (2008) tersebut mampu menjadi penjelas bahwa secara umum informan telah berfungsi sebagai pelaksana aktivitas literasi media yang aktif. Informan telah mampu ikut berperan serta dalam lingkungannya untuk memberikan sebuah solusi meski minimalis atas adanya dampak negatif dan atau adanya penyimpangan dalam penggunaan media sosial. Dalam dunia literasi media digital tidak saja membutuhkan kemampuan teknis untuk mengakses teknologi tetapi juga memahami konten, fungsi aktif dan interaktif saat memproduksi pesan. Lebih dari itu interaksi di dalam literasi media digital akan membawa konsekuensi terhadap keamanan diri, privasi, konsumsi berlebihan, dan proses menyikapi perbedaan yang terjadi.

\section{Simpulan}

Berdasar dari hasil penelitian dan pembahasan maka dapat diambil beberapa kesimpulan sebagai penutup laporan penelitian ini sebagai berikut:

Informan mahasiswa Jurusan Ilmu Komunikasi FISIP Unsoed memiliki alasan dan motivasi tertentu dalam menggunakan media sosial sesuai kebutuhan mereka dan kekhasan media sosial yang ada, baik dari bertukar informasi dan menjaga pertemanan hingga alasan proses pembelajaran, ekonomi, hiburan, dan aktualisasi diri. Informan mahasiswa Jurusan Ilmu Komunikasi FISIP Unsoed telah mengetahui adanya dampak negatif dan penyimpangan yang terjadi akibat penggunaan media sosial yang tidak sesuai. Mereka juga telah memiliki caracara untuk ampuh meredam dampak buruk yang dapat terjadi dalam penggunaan media sosial yang ada. Informan mahasiswa Jurusan Ilmu Komunikasi FISIP Unsoed menyatakan perlu adanya kegiatan literasi media untuk mencegah terjadinya adanya dampak negatif penggunaan media sosial bagi mereka. Namun beberapa di antara informan menyatakan bahwa telah ikut terlibat aktif dalam kegiatan sosialisasi dan pelatihan tentang literasi media.

\section{Daftar Pustaka}

Amrullah. 2016. Makalah Cyber Media. Jakarta: sebuah makalah.

Angeliqa, Fitria. 2016. Habitus Remaja dalam Literasi Media Online. The 3rd Indonesia Media Research Awards \& Summit (IMRAS). Jakarta: Serikat Perusahaan Pers.

Aras, Muhammad. 2016. Media Sosial dan Pemilukada di Indonesia. The 3rd Indonesia Media Research Awards \& Summit (IMRAS). Jakarta: Serikat Perusahaan Pers.

Bawden, D. 2001. Information and Digital Literacies: a review of concepts. Journalof documentation, 57(2), 218-259.

Buckingham, D. 2007. Digital Media Literacies: rethinking media education in the age of the Internet. Research in Comparative and International Education, 2 (1), 43-55.

Fitryarini, Inda. 2016. Literasi Media Pada Mahasiswa Prodi Ilmu Komunikasi Universitas Mulawarman. Jurnal Komunikasi. Vol 8, No 1 (2016). Diakses dalam https://journal.untar.ac.id/index. php/komunikasi/article/view/46

Gracia Rachmi Adiarsi, Yolanda Stellarosa, Martha Warta Silaban. 2015. Literasi 
Media Internet di Kalangan Mahasiswa. Jurnal Humaniora Vol 6, No 4 (2015) diakses dalam http://journal.binus.ac.id/ index.php/Humaniora/article/view/3376.

Handoko, Hani T. dan Reksohadiprodjo, Sukanto.1996. Organisasi Perusahaan. Edisi kedua. Yogyakarta : BPFE

Herlina S, Dyna. 2017. Membangun Karakter Bangsa melalui Literasi Digital. Yogyakarta: Japelidi

Istiyanto, S. Bekti. 2015. Telepon Genggam dan Perubahan Sosial. Jakarta: Jurnal Komunikasi Ikatan Sarjana Komunikasi Indonesia (ISKI): Volume 2 No 2 Edisi Juli-Desember 2015. ISSN 0853-4470.

Kasto. 1998. Metode Pengumpulan Data. Jakarta: LP3ES.

Kurnia, Novi., dkk. 2017. Pemetaan Gerakan Dan Isu Literasi Digital Di Indonesia. Yogyakarta: Program Pascasarjana Komunikasi FISIPOL UGM.

Kurniawati, Juliana. 2016. Literasi Media Digital Mahasiswa Universitas Muhammadiyah Bengkulu (Survei Tingkat Literasi Media Digital pada Mahasiswa Universitas Muhammadiyah Bengkulu Ditinjau dari Aspek Individual Competence). Jurnal Komunikator Vol 8, No 2 (2016) diakses dalam http://journal.umy. ac.id/index.php/jkm/article/view/2069

Martin, Allan. 2008. Digital Literacy and the 'Digital Society' dalam Lankshear, C and Knobel, M (ed). Digital literacies: concepts, policies and practices. Die Deutsche Bibliothek.

Miles, B. M. \& Huberman A. M. 1992. Analisis Data Kualitatif, Buku Sumber tentang Metode-Metode Baru. Jakarta: Penerbit UI Press.

Moleoeng, Lexy J. 2000. Metode Penelitian Kualitatif. Cetakan ke-12. Bandung: Remaja Rosdakarya.
Nasution, Zulkarimein. 2004. Perkembangan Teknologi Komunikasi. Jakarta: Universitas Terbuka.

Poerwaningtias, Intania, dkk. 2013. ModelModel Gerakan Literasi Media Dan Pemantauan Media Di Indonesia. Yogyakarta: Pusat Kajian Media dan Budaya Populer dan Yayasan TIFA.

Potter, W. James. 2011. Media Literacy. Fifth Edition. Los Angeles, London, New Delhi, Singapore, Washington DC: Sage Publication.

Riel, J., Christian, S., \& Hinson, B. 2012. Charting Digital Literacy: A framework for information technology and digital skills education in the community college. Presentadoen Innovations.

Rogers, Everett M. 1992.Komunikasi dan Pembangunan Perspektif Kritis. Jakarta: LP3ES.

Sudarmanti, Rini \& Yusuf, Kurniawaty. 2016. Pemanfaatan Media Sosial sebagai Media Komunikasi Ibu dan Anak Remaja. The 3rd Indonesia Media Research Awards \& Summit (IMRAS). Jakarta: Serikat Perusahaan Pers.

Triastuti, Endah, dkk. 2017. Kajian Dampak Penggunaan Media Sosial Bagi Anak dan Remaja. Jakarta: Puskakom

Internet :

APJII. 2016. Survei Internet. Diunduh melalui link http://www.apjii.or.id/survei atau http://www.apjii.or.id/survei2016.

https://kominfo.go.id/content/ detail/4286/pengguna-internetindonesia-nomor-enam-dunia/0/ sorotan media.

http:/ciricara.com/2012/10/19/indonesiamasuk-daftar-negara-dengan-kasusbullying-tertinggi/ 